\title{
In-vivo Assessment of Tranquilizer Activity of Various Extracts of Cajanus cajan Leaves in Mice
}

\author{
Balakrishna Vuyyala ${ }^{1, *}$, D Senthil Kumar ${ }^{2}$, Thakkalapally Lakshmi ${ }^{3}$ \\ ${ }^{1}$ Department of Pharmacology, Gurunanak Institutions Technical Campus, Khanapur, Rangareddy Dist. and Research Scholar, \\ Annamalai University, Chidambaram, India \\ ${ }^{2}$ Department of Pharmacology, Annamalai University, Chidambaram, India \\ ${ }^{3}$ Department of Pharmacology, Gurunanak Institutions Technical Campus, Khanapur, Rangareddy Dist., India
}

Received June 14, 2021; Revised July 19, 2021; Accepted August 22, 2021

\section{Cite This Paper in the following Citation Styles}

(a): [1] Balakrishna Vuyyala, D Senthil Kumar, Thakkalapally Lakshmi , "In-vivo Assessment of Tranquilizer Activity of Various Extracts of Cajanus cajan Leaves in Mice," Advances in Pharmacology and Pharmacy, Vol. 9, No. 4, pp. 87 - 93, 2021. DOI: 10.13189/app.2021.090402.

(b): Balakrishna Vuyyala, D Senthil Kumar, Thakkalapally Lakshmi (2021). In-vivo Assessment of Tranquilizer Activity of Various Extracts of Cajanus cajan Leaves in Mice. Advances in Pharmacology and Pharmacy, 9(4), 87 - 93. DOI: 10.13189/app.2021.090402.

Copyright $\bigcirc 2021$ by authors, all rights reserved. Authors agree that this article remains permanently open access under the terms of the Creative Commons Attribution License 4.0 International License

\begin{abstract}
Background: Cajanus cajan is a legume of the plant family Fabaceae. Another name of this plant is the red gram, gungo pea, and no-eye pea. It is a multifaceted plant as it is widely often consumed as a dal. It contains wealthy proteins. The whole plant parts are utilized for silkworms as a vegetable; tops, green leaf, and husk are utilized as feed. Objective: The objective of the analysis was to determine the anti-anxiety effect of varied extracts viz n-hexane, chloroform, ethyl acetate, and methanol of the leaves of Cajanus cajan with an EPM (Elevated plus maze) as well as actophotometer model in albino mice. Methods: In the present research, the anti-anxiety activities of several extracts were evaluated viz n-hexane, chloroform, ethyl acetate, \& methanol of the leaves of Cajanus cajan with an EPM model in albino mice. Albino mice have ministered with varied extract dosages orally (for example, $200 \& 400 \mathrm{mg} / \mathrm{kg}$ ) and behaviour on the EPM has been seen. The standard usage of Diazepam (2 $\mathrm{mg} / \mathrm{kg}$ P.O.) (positive control). Results: Results indicate that the methanolic extract of $C$. cajan manifested a significant as well as maximum dose-dependent impact at $200 \& 400 \mathrm{mg} / \mathrm{kg}$ on mice with the help of the EPM model and the results were exactly like diazepam $(2 \mathrm{mg} / \mathrm{kg})$, the standard antianxiety substance. The model actophotometer exhibited a dose-dependent reduction in locomotor activity compared to control animals, which is shown at two distinct dosages $(200 \& 400 \mathrm{mg} / \mathrm{kg})$ of Cajanus cajan. Conclusion: The content of polyphenols was shown in the
\end{abstract}

phytochemical test for methanol extract, which could be liable for the anxiolytic potential of Cajanus cajan. This plant might thus also be cultivated as a potentially beneficial anti-anxiety substance.

Keywords Cajanus cajan, Actophotometer, Diazepam, Elevated Plus Maze, Anxiety

\section{Introduction}

Anxiety is a natural human state which everybody experiences in their lives. Anxiety is the foremost common psychological state problem within the world and it increases rapidly [1]. Mental disorders occurrence is increasing. Many severe adverse effects; and addiction liabilities have been observed with chronic use of prescribed synthetic drugs. This led the way for the researchers towards natural tranquilizer sources. It can prompt us to confront difficult challenges that cause us to become psychologically disturbed and; unhealthy, and produce anxious disorders like panic attacks, phobias, and obsessional behaviours.

Benzodiazepine, being a big category of agents used for hysteria [2], shows a lean safety border between the tranquilizers and undesirable side effects, which made investigators concentrate on medicinal plants with 
anxiolytic effects with gauge the less undesirable effects [3].

C. cajan is a legume of the plant family Fabaceae. Another name of this plant is the red gram, gungo, \& no-eye pea [4]. They desire to grow this plant from at least three thousand years ago. Asia, Africa, and probably the origin of this plant and employing the slave trade to the American continent. In the world creation, India is a foremost developing nation contributing almost $92 \%$ of Cajanus cajan cultivation. At present, it has a 3.80 million hectares area with yearly growth of 2.65 million tons [5]. It is a multifaceted plant as it is widely fed as a dal. It contains wealthy proteins, the whole plant parts are utilized for silkworms as a vegetable; tops, green leaf, and husk are utilized as feed [6].

Amongst its numerous therapeutic usages, C. cajan is demonstrated as a sedative with the help of agony in customary Chinese medication [7]. As of late, it has been additionally investigated to treat ischemic putrefaction of the caput femoris, bedsore, aphtha, and wound mending. Concoction examinations have uncovered the nearness of two globulins, concajanin, \& cajanin [8]. It was utilized generally for a long time to treat diabetes, injuries, hepatitis, skin disturbances, jaundice, measles, looseness of the bowels, and numerous different ailments; remove bladder stones and balance out the menstrual period [9].

Compound constituent examinations have demonstrated that leaves of $C$. cajan are wealthy in stilbenes as well as flavonoids. Saponins, obvious measures of tannins, and modest amounts of lessening sugars, terpenoids \& tars are also included. Synthetic examinations uncover 2'-2' methyl cajanone, 2'- hydroxy genistein, isoflavones, cahanones, cajanin, and so on, which grant cancer prevention agent properties [10]. In addition, genistin as well as genistein are identified in the roots. It additionally includes hexadecanoic corrosive, $\beta$-sitosterol, $\alpha$ amyrin, longistylin A, Pinostrobin, and longistylin $\mathrm{C}$ imparting anti-cancer movement. The nearness of cajanuslactone, a coumarin gives antibacterial movement. The nearness of cajaninstilbene corrosive, orientin, vitexin, and pinostrobin is liable for the antispasmodic movement.

\subsection{Ethnopharmacology}

As a forage crop, Cajanus cajan was used as a significant remedy for several conditions [11]. Ethnopharmacological uses of $C$. cajan are shown in Table 1.
Table 1. Ethnopharmacological usage of C. cajan

\begin{tabular}{|c|c|c|c|}
\hline S.no & Part & Aliment & Community/group \\
\hline (1) & Leaf juice & Diabetes & $\begin{array}{c}\text { Diabetes Garo tribe } \\
\text { Bangladesh [10] }\end{array}$ \\
\hline (2) & Seed paste & Energy stimulant & $\begin{array}{c}\text { Garo tribe of } \\
\text { Bangladesh [10] }\end{array}$ \\
\hline (3) & Leaf & $\begin{array}{c}\text { Food poisoning, } \\
\text { colic, constipation }\end{array}$ & $\begin{array}{c}\text { Trinidad and } \\
\text { Tobago [6] }\end{array}$ \\
\hline (4) & Leaf & $\begin{array}{c}\text { Staunch blood } \\
\text { for killing parasites } \\
\text { as an analgesic }\end{array}$ & $\begin{array}{l}\text { Chinese folk } \\
\text { medicine }\end{array}$ \\
\hline (5) & $\begin{array}{l}\text { Leaf, young } \\
\text { stems, } \\
\text { seeds, } \\
\end{array}$ & $\begin{array}{c}\text { Gingivitis, } \\
\text { Toothbrush, } \\
\text { stomatitis }\end{array}$ & $\begin{array}{c}\text { Tamil Nadu (India) } \\
{[7]}\end{array}$ \\
\hline (6) & $\begin{array}{l}\text { Fresh leaf } \\
\text { juice }\end{array}$ & $\begin{array}{c}\text { Laxative, } \\
\text { Nullification of } \\
\text { intoxication } \\
\end{array}$ & $\begin{array}{c}\text { Rajasthan (India) } \\
{[8]}\end{array}$ \\
\hline (7) & Leaf paste & $\begin{array}{c}\text { Oral ulcers } \\
\& \text { Inflammation } \\
\end{array}$ & $\begin{array}{c}\text { Rajasthan (India) } \\
{[8]}\end{array}$ \\
\hline (8) & $\begin{array}{l}\text { Seeds \& } \\
\text { Leaf }\end{array}$ & $\begin{array}{c}\text { Applied over the } \\
\text { breast for inducing } \\
\text { lactation }\end{array}$ & $\begin{array}{c}\text { Rajasthan (India) } \\
{[8]}\end{array}$ \\
\hline
\end{tabular}

\section{Material \& Method}

\subsection{Authentication of Plant Material}

The Cajanus cajan leaves were gathered from the medicinal plants' farm, Karimnagar district, Telangana state. The plant identification was authenticated by Dr. E. Narasimha Murthy, Satavahana University. A representative sample placed within the Herbarium of Satavahana University and the plant specimen no. ENM/SU 0019024.

\subsection{Animals}

Swiss albino mice were procured from Mahaveer enterprises, Guru Nanak Institute of Pharmacy, Hyderabad, and fed with water ad-lib as well as a typical pellet diet. The animals were of 6 to 8 weeks of age weighing about $25 \pm 5 \mathrm{~g}$ were used in this study. These allowed getting laboratory conditions for a week. The animals were needed to maintain under the conditions like light/dark cycles, the temperature at $22 \pm 3{ }^{\circ} \mathrm{C}$ with $65 \pm 5 \%$ relative humidity. Each group contains 6 animals of both gender through the entire anxiolytic screening that was performed randomly. The IAEC ("Institutional Animal Ethics Committee of the Institute"), Guru Nanak Institutions Technical Campus -School of Pharmacy approved the experimental protocol (the approval number: (06/GNIP/CPCSEA/IAEC/2019). 


\subsection{Drugs and Chemicals}

Various chemicals were used to obtain desired phytochemical constituent: n-hexane $\left(60-80^{\circ} \mathrm{C}\right)$, ethyl acetate and methanol ("S. D. Fine Chemicals"), \& chloroform ("Ranbaxy Laboratory chemicals"), all LR grade. For assessment of the anti-anxiety effect, standard medication Diazepam (Jawa Pharmaceuticals Pvt. Ltd., Gurgaon) was employed.

\subsection{Extract Preparation}

Coarsely powdered leaves of Cajanus cajan (Fig. 1) $(250 \mathrm{~g})$ were powdered (\#60). And various solvents are using n-hexane; methanol, ethyl acetate, \& chloroform have been subjected to exhaustive soxhlet extraction $[12,13]$. Eyela N 1100 rotating evaporator [14] was used to recover all solvents from all extracts.

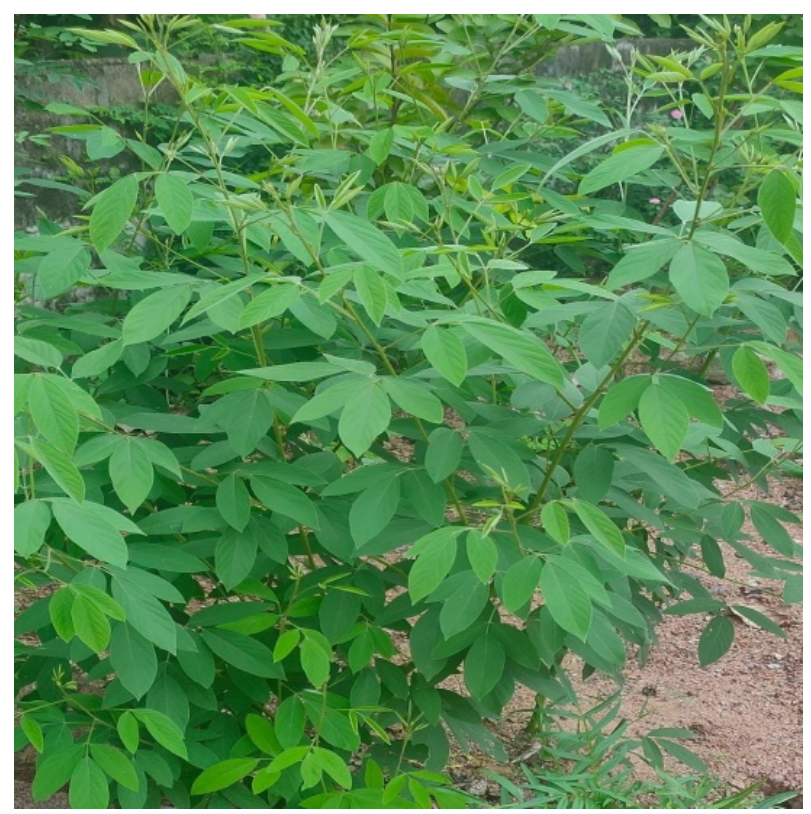

Figure 1. Leaves of Cajanus cajan

\subsection{Vehicle and Standard}

A suspension was prepared for different doses of plant extracts using $\mathrm{CMC}$ with $5 \%$ tween 80 was utilized as a vehicle. For assessment of the anti-anxiety effect, standard medication Diazepam was employed. The group administered with vehicle behaves as control.

\subsection{Preparation of Doses}

Two different doses of test substances with concentrations respectively by dispersion in a suitable vehicle. The test doses were treated orally with an oral feeding tube to mice in a volume various from $0.10-1 \mathrm{ml}$. Diazepam was treated with the ip route.

\subsection{Acute Oral Toxicity Trials}

According to OECD 423 guidelines, acute toxicity trials for all test substances have been undertaken [15].

\subsection{EPM Model}

The EPM is comprised of two open as well as two closed arms with an open roof, which keeps elevating from the floor for [16]. During the whole experiment, mice are allowed to interact (socialize). Precautions are taken in such a way that no external stimuli influence the anxiolytic activity. Drugs were administered prior to 1hour, of the experiment, wherein the animals are positioned in the middle of EPM with their head towards the open arm. The cut-off time is $5 \mathrm{~min}$ for reading the behaviour of an animal in context of mean time and no. of entries in open arm [17].

\subsection{Digital Actophotometer}

\section{Procedure}

A continuous beam of sunshine from six lights is going to be made to fall on corresponding photoelectric cells, the photoelectric cells will get activated when an animal crosses the beam of light, thereby cutting off (crossing) the rays of light falling on it. The machine was min for 10 min to get the count. This count reflects the locomotor activity of the mice. Mice are placed in the digital Actophotometer for one hour. After drug administration and the number of crossings is counted for ten minutes [17].

\subsection{Statistical Analysis}

The results belong to our work performed as regards mean \pm SEM and were displayed to Tukey's multiple comparison analysis as well as one-way ANOVA to gauge the significant tests. A P-value (Probability) below 0.05 is regarded as statistically significant.

\subsection{Phytochemical Screening}

The screening was conducted for major constituents with antianxiety activity [18].

\section{Results}

\subsection{Extract Yield (\%)}

Table 2 illustrates different extract yields. Table 3 summarises the aerial parts of plant extracts for plant chemical constituents screening. 


\subsection{Acute Toxicity Studies}

The several C. cajan extracts were safe according to acute toxicity studies nor mortality up to the dosage of $2000 \mathrm{mg} / \mathrm{kg}$, p.o.

\subsection{Phytochemical Screening}

Methanolic C. cajan flower extract contains flavonoids, phytosterols, terpenoids, tannins, phenols, and carbohydrates $[19,20]$.

\subsection{Pharmacological Activity}

The tranquilizer activity was fixed on the Cajanus cajan by using EPM and actophotometer instruments. The mean time spent in open arms and no. of entries into open arms by mice after oral treatment of doses $200 \mathrm{mg} / \mathrm{kg}$ and $400 \mathrm{mg} / \mathrm{kg}$ of all extracts.

Table 2. The yield (w/w) of various extracts of $C$. cajan leaves

\begin{tabular}{|c|c|c|}
\hline S.No & Extract & Cajanus cajan \\
\hline 1. & n-hexane & 2.64 \\
\hline 2. & Chloroform & 1.46 \\
\hline 3. & Ethyl acetate & 9.48 \\
\hline 4. & Methanol & 14.26 \\
\hline
\end{tabular}

Table 3. Phytochemical screening of various extracts of Cajanus cajan leaves

\begin{tabular}{|c|c|c|c|c|}
\hline Class of Phytoconstituents & n-Hexane extract & Ethyl acetate extract & Chloroform extract & Methanol extract \\
\hline Anthraquinone glycosides & - & - & - & - \\
\hline Alkaloids & - & - & - & - \\
\hline Cardiac glycosides & - & + & - & - \\
\hline Steroids/Triterpenoids & $-/-$ & $+/-$ & + & $-/-$ \\
\hline Coumarins & - & + & - & - \\
\hline Saponins & - & + & + & + \\
\hline Tannins & - & + & - & + \\
\hline Flavonoids & - & + & + & + \\
\hline Carbohydrates & - & + & + \\
\hline Aminoacids & - & + & + \\
\hline
\end{tabular}

Table 4. The anti-anxiety effect of varied Cajanus cajan leaves extracts in EPM and Actophotometer

\begin{tabular}{|l|c|c|c|c|c|}
\hline \multirow{2}{*}{ S. No } & Treatment & Dosage (mg/kg) & $\begin{array}{c}\text { Mean* no. of entries in } \\
\text { open arms }\end{array}$ & $\begin{array}{c}\text { Mean* time spent in } \\
\text { open arm (seconds) }\end{array}$ & Locomotor activity \\
\hline$(1)$ & Control & Vehicle & $2.3 \pm 0.21^{\mathrm{b}, \#}$ & $2.8 \pm 0.30^{\mathrm{b}, \#}$ & $196.50 \pm 9.01^{\mathrm{b}, \#}$ \\
\hline$(2)$ & Diazepam & 2.0 & $7.2 \pm 0.40^{\mathrm{a}, \#}$ & $14.5 \pm 0.42^{\mathrm{a}, \#}$ & $344.83 \pm 12.86^{\mathrm{a}, \#}$ \\
\hline \multirow{2}{*}{$(3)$} & \multirow{2}{*}{ n-hexane extract } & 200 & $2.5 \pm 0.22^{\mathrm{b}, \#}$ & $2.3 \pm 0.21^{\mathrm{b}, \#}$ & $218.66 \pm 6.40^{\mathrm{b}, \#}$ \\
\cline { 3 - 6 } & & 400 & $2.8 \pm 0.30^{\mathrm{b}, \#}$ & $2.6 \pm 0.33^{\mathrm{b}, \#}$ & $234.33 \pm 36.43^{\mathrm{b}, \$}$ \\
\hline \multirow{2}{*}{$(4)$} & \multirow{2}{*}{ Chloroform extract } & 200 & $4.1 \pm 0.30^{\mathrm{a}, \mathrm{s}, \mathrm{b} \#}$ & $5.6 \pm 0.21^{\mathrm{a}, \mathrm{b}, \#}$ & $232.83 \pm 16.7^{\mathrm{b}, \$}$ \\
\cline { 3 - 6 } & & 400 & $4.3 \pm 0.42^{\mathrm{a}, \mathrm{S}, \mathrm{b} \#}$ & $6.5 \pm 0.22^{\mathrm{a}, \mathrm{b}, \#}$ & $248.5 \pm 24.61^{\mathrm{b}, @}$ \\
\hline \multirow{2}{*}{$(5)$} & \multirow{2}{*}{ Ethyl acetate extract } & 200 & $3.8 \pm 0.30^{\mathrm{a}, \mathrm{a}, \mathrm{b}, \#}$ & $5.8 \pm 0.30^{\mathrm{a}, \mathrm{b}, \#}$ & $262.83 \pm 16.7^{\mathrm{b}, @}$ \\
\cline { 3 - 6 } & & 400 & $4.8 \pm 0.30^{\mathrm{a}, \mathrm{b}, \#}$ & $7.2 \pm 0.21^{\mathrm{a}, \mathrm{b}, \#}$ & $278.16 \pm 24.61^{\mathrm{b}, \Theta}$ \\
\hline \multirow{2}{*}{$(6)$} & \multirow{2}{*}{ Methanol extract } & 200 & $4.3 \pm 0.21^{\mathrm{a}, \mathrm{S}, \mathrm{b}, \#}$ & $7.3 \pm 0.42^{\mathrm{a}, \mathrm{b}, \#}$ & $283.16 \pm 9.69^{\mathrm{a}, @}$ \\
\cline { 3 - 6 } & & 400 & $5.3 \pm 0.33^{\mathrm{a}, \#, \mathrm{~b}, \$}$ & $8.1 \pm 0.30^{\mathrm{a}, \mathrm{b}, \#}$ & $291.33 \pm 14.52^{\mathrm{a}, \$}$ \\
\hline
\end{tabular}

$\mathrm{n}=6 .{ }^{\circledR} \mathrm{p}<0.05,{ }^{\mathrm{s}} \mathrm{p}<0.01,{ }^{\#} \mathrm{p}<0.001 .{ }^{\mathrm{a}}$ : vs. control, ${ }^{\mathrm{b}}$ : vs. diazepam, One-way ANOVA is followed by Tukey's multiple comparison test. In figure, the doses are $\mathrm{mg} / \mathrm{kg}$ 


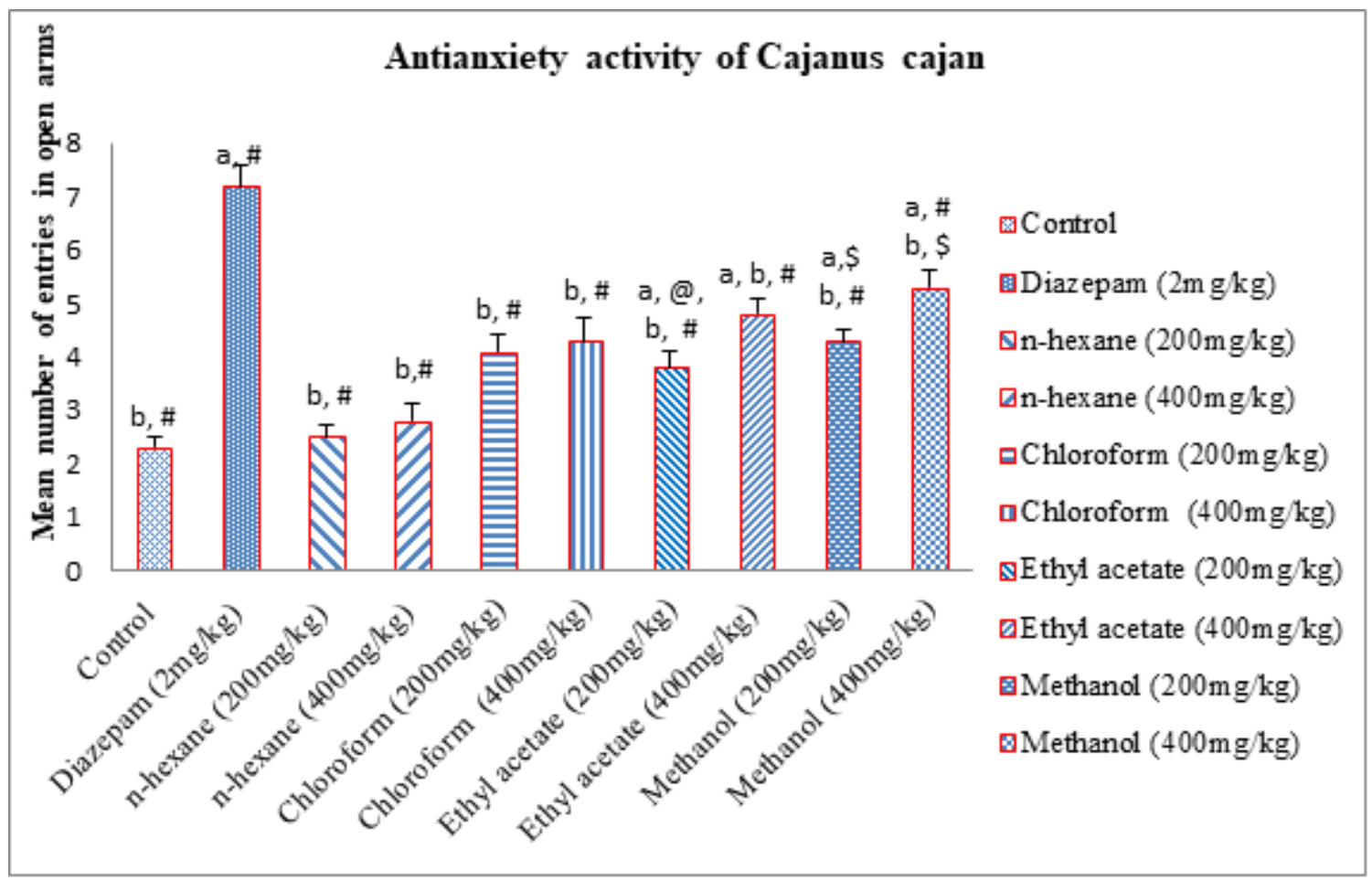

Figure 2. Antianxiety activity profile of various extracts of Cajanus cajan leaves by using EPM.

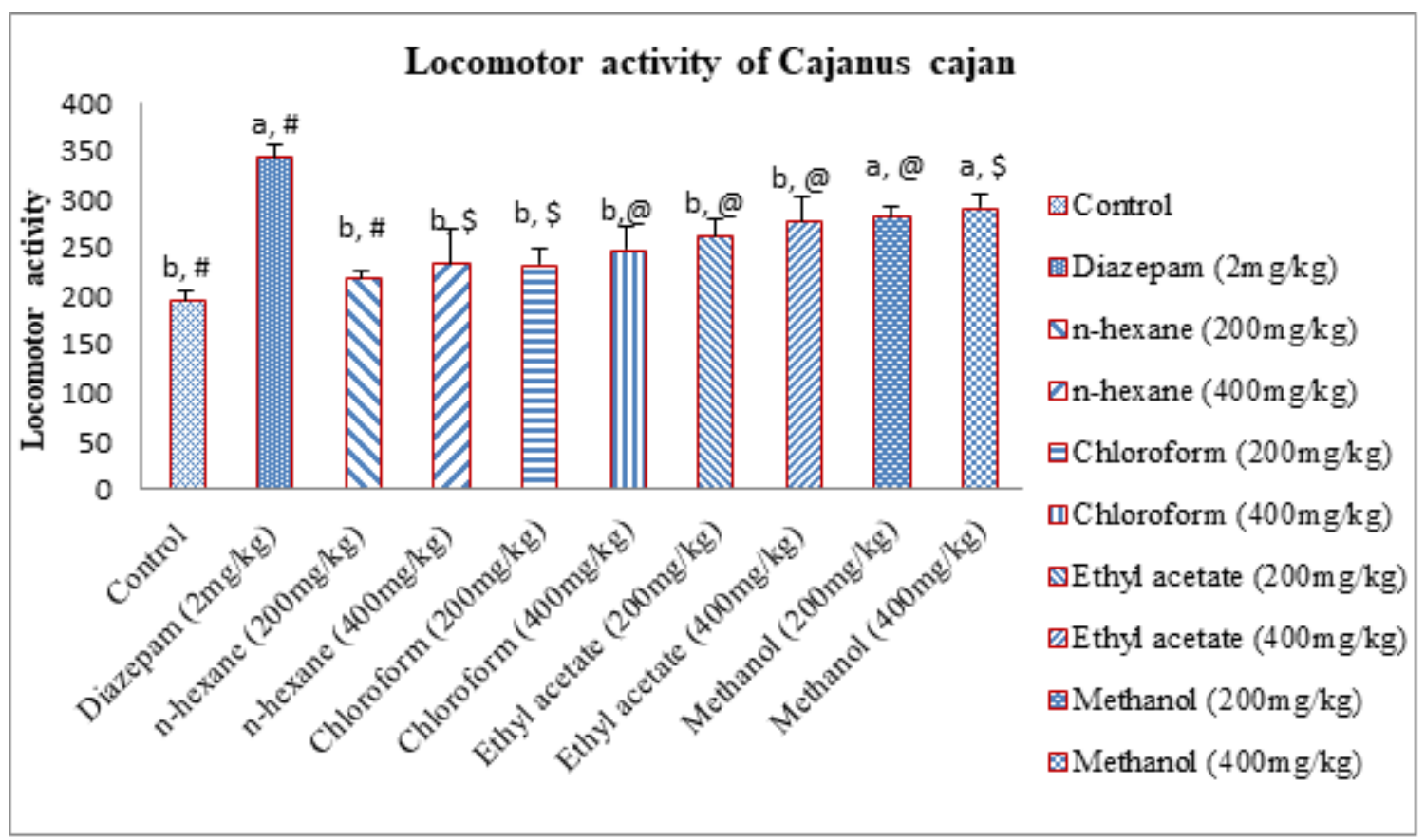

Figure 3. Antianxiety activity profile of various extracts of Cajanus cajan leaves by using Actophotometer. 


\section{Discussion}

Major types of drugs to treat anxiety ailments are the continued use of Benzodiazepines (BZDs), barbiturates, and Tricyclic antidepressants (TCAs) which are the most prescribed anxiolytics, which leads to deterioration of memory accompanied by tolerance and addiction [21]. An essential step in finding out the drug effects on CNS is to observe its effect on locomotors activity of the animal.

Amongst various extracts methanol extract and chloroform extract of Cajanus cajan at the various doses of $200 \mathrm{mg} / \mathrm{kg} \& 400 \mathrm{mg} / \mathrm{kg}$ increased greatly concerning to control, the mean time spent in open arms and a mean no. of entries into open arm in mice with EPM apparatus, thereby producing anxiolytic activity. The various dosages of 200 , as well as $400 \mathrm{mg} / \mathrm{kg}$, revealed a greatly anxiolytic effect shown in figure 2 with a significant dose-dependent manner shown in Table 4 [22].

In the Actophotometer model, locomotor activity (behavioral activity) is measured and compared between the groups. Standard drug Diazepam significantly depleted the no. of outcrossed light beams compared to

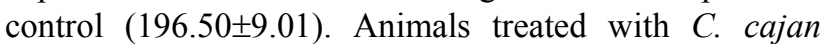
$400 \mathrm{mg} / \mathrm{kg}$ exhibited a greater decrease in locomotor activity (291.33 \pm 14.52$)$ than animals treated with $C$. cajan $200 \mathrm{mg} / \mathrm{kg}$ (283.16 \pm 9.69$)$; and therefore, it showed a statistically significant dose-dependent anxiolytic effect of C. cajan (Table 3). The reduction in locomotor activity with $200 \mathrm{mg} / \mathrm{kg}$ and $400 \mathrm{mg} / \mathrm{kg}$ is significant when compared to the standard group $(344.83 \pm 12.86)$ shown in figure 3 .

Neither of the other extracts showed any dosage of anti-anxiety effect [23]. The content of flavonoids, tannins [24], as well as carbohydrates, was shown by the phytochemical screening of methanol extract. In different studies, flavonoids showed anti-anxiety effects. In addition, anxiolytic effects on the central nervous systems [25] as well as benzodiazepine receptors [26, 27] have been attributed to Flavonoids. Thus, the anti-anxiety effect is attributed to flavonoids of $C$. cajan's methanolic extract.

\section{Conclusion}

The current investigation reveals that the methanolic extract of C.cajan manifested a significant as well as maximum dose-dependent impact at 200 and $400 \mathrm{mg} / \mathrm{kg}$ in mice with the help of the EPM model and locomotor activity of anxiety. The tests are underway to extract bioactive fraction/constituent(s) from Cajanus cajan accountable for the anti-anxiety effect.

\section{Abbreviations}

CPCSEA - Committee for the Purpose of Control \&
Supervision of Experiments on Animals

EPM - Elevated plus maze

GNIP - Guru Nanak Institute of pharmacy

IAEC - Institutional Animal Ethics Committee

OECD - Organisation for Economic Co-operation \&

Development

ORR - Outer ring road

P.O - Per Oral

SEM - Standard error of the mean

\section{REFERENCES}

[1] David ME., Davis RB., Ettner SL., Appel S., Wilkey S., Van Rompay M., Kessler RC, "Trends in alternative medicine use in the United States 1990-1997: results of a follow-up national survey", Journal of the American Medical Association, Vol. 280, no. 18, pp. 1569-1575, 1998.

[2] Lader M., Morton, S, "Benzodiazepine problems", British journal of addiction, Vol. 86, no. 7, pp. 823-828, 1991.

[3] Griffiths RR., Ator N., Roache JD., Lamb R, “The abuse liability of triazolam: experimental measurements in animals and humans", Psychopharmacology, Vol. 3, no. 5, pp. 83-87. 1987.

[4] Nan W., Fu K., Fu YJ., Zu YG., Chang FR., Chen YH, "Antioxidant activities of extracts and main components of pigeon pea leaves", Molecules, Vol. 14, no. 3, pp. 1032-1043, 2009.

[5] Kumar H., Bajpai VK., Dubey RC, Maheshwari., Kang, SC, "Wilt disease management and enhancement of growth and yield of $C$. cajan by bacterial combinations amended with chemical fertilizers", Crop protection, Vol. 29, no. 6, pp. 591-598, 2010.

[6] Raisa K., Farhana M., Muhammad J, "Antioxidant evaluations of polar and non-polar fractions of Cajanus cajan seeds", Journal of medicinal plants research, Vol. 9, no. 6, pp. 193-198, 2015.

[7] Ahsan R., Islam M, "In vitro antibacterial screening and toxicological study of some useful plants (Cajanus cajan)", European journal of scientific research, Vol. 41, pp. 227-32, 2009.

[8] Yuan-gang Zu., Xiao-lei Y., Yu-Jie Fu., Nan Wu., YuKong $\mathrm{Zu}$., Michael W, "Chemical composition of the SFE-CO2 extracts from Cajanus cajan (L.) Huth and their antimicrobial activity in vitro and in vivo", Phytomed, Vol. 17, pp. 1095-1001, 2010.

[9] Kong Y., Fu YJ., Zu YG., Chang FR., Chen YH., Liu XL., "Cajanuslactone a new coumarin with anti-bacterial activity from pigeon pea leaves", Food Chemicals, Vol. 121, pp. 1150-1155, 2010.

[10] Pal D., Sarkar A., Gain S., Jana S., Mandal S, "CNS depressant activities of Coccos Nucifera in mice", Acta Poloniae Pharmaceutica, Vol. 68, pp. 249-254, 2011.

[11] Duke JA, "Handbook of legumes of world economic 
importance", New York: Plenum Press 2004; pp. 33-40.

[12] Balakrishna V., Senthilkumar D., Lakshmi T, “Tamarindus indica L. (Fabaceae): Extent of explored use in traditional medicine", Asian journal of pharmaceutical and clinical research, Vol. 13, no.3, pp. 28-32, 2020.

[13] Vaishnavi V., Bhargavi RT., Baba Shankar RG., Ram Mohan M., Vasudha B, (2019). "Isolation, characterization, and assessment for central nervous system effects of novel Phyto molecule from Galphimia glauca Cav. Stems", Asian Journal of Chemistry, Vol. 31, no.6, pp.1230-1236, 2019.

[14] Trease EG., Evans WC, "Textbook of Pharmacognosy", 12th edn. Alden Press, London, 1983, pp. 343-383.

[15] OECD Guidelines for the Testing of Chemicals (No. 423): Acute Oral Toxicity-Acute Toxic Class Method (Adopted on 17 December 2001).

[16] Paladini AC., Marder M., Viola H., Wolfman C., Wasowaki C., Medina JH, "Flavonoids and the central nervous system: from forgotten factors to potent anxiolytic compounds" Journal of Pharmacy and Pharmacology, Vol. 51, no. 5, pp. 519-526, 1999.

[17] Halemani D, "Evaluation of anti-anxiety activity of methanol extract of Aegle maemelos (Bael fruit tree) leaves in rats", IOSR Journal of Dental and Medical Sciences, Vol. 14, no.9, pp.01-05, 2015.

[18] Ashwani K., Jitender S., Anupam S, "Comparative antianxiety activity evaluation of Argyreia speciosa linn. (Roots), Caesalpinia digyna rottler (Roots) and Sphaeranthus indicus linn. (Flowers)", International journal of pharmaceutical sciences and research, Vol. 6, no.10, pp. 4226-4229, 2015

[19] Padmini I., Vishal G, "Development and evaluation of nanosponge loaded topical herbal gel of Wrightia tinctoria", International journal of applied pharmaceutics, Vol. 12, no.1, pp. 89-95, 2020.

[20] Durga D., Khaga RS, "Estimation of total phenol and antioxidant activity of zanthoxylum armatum of Nepalese origin", International journal of current pharmaceutical research, Vol. 12, no.4, pp. 37-40, 2020.

[21] Longo LP., Johnson B, "Addiction: Part I. Benzodiazepines-side effects, abuse risk, and alternatives", American Family Physician, Vol. 61, pp. 2121-2128, 2000.

[22] Vogel HG., Vogel WH., Scholkens BA., Sandow J., Miller G., Vogel WF, "Pharmacological assays, drug discovery, and evaluation", Springer Verlag, Germany; pp. 368-370, 2002.

[23] Sanoria S., Latief QZ., Gautam SP., Amit B, "Cassia Fistula: Botany, Phytochemistry and Pharmacological Leverages-A Review", International Journal of Pharmacy and Pharmaceutical Sciences, Vol. 12, no.6, pp. 1-7, 2020.

[24] Ibrahim F., Jaber A., Ibrahim G., Cheble E, “Antioxidant activity and total phenol content of different plant parts of Lebanese Annona squamosa linn", International journal of pharmacy and pharmaceutical sciences, Vol. 12, no.8, pp. 100-105, 2020.

[25] Medina JH, Viola H, Wolfman C, Marder M, Wasowski C, Clavo D, Paladini AC, "Neuroactive flavonoids: new ligands for the benzodiazepine receptors", Phytomed, Vol. 5, pp. 235-243, 1997.

[26] Kulkarni SK., Reddy DS, "Models for Testing Anti-anxiety Agents", Methods and Findings in Experimental and Clinical Pharmacology, Vol. 18, pp. 219-240, 1996.

[27] Wolfman C., Viola H., Paladini A., Dajas F., Medina JH, "Possible anxiolytic effects of chrysin, a central benzodiazepine receptor ligand isolated from Passiflora coerulea", Pharmacology Biochemistry \& Behavior, Vol. 47, no. 1, pp. 1-4, 1994. 